\title{
¿Climate Change, Agency Decision-Making, and the Resilience of Land-Based Livelihoods
}

\author{
CORRINE NOEL KNAPP \\ Haub School of Environment and Natural Resources, University of Wyoming, Laramie, Wyoming \\ SHANNON M. MCNEELEY \\ Natural Resource Ecology Laboratory, Colorado State University, Fort Collins, Colorado \\ JOHN GIOIA \\ Western Colorado University, Gunnison, Colorado \\ TREVOR EVEN \\ Colorado State University, Fort Collins, Colorado \\ TYLER BEETON \\ Natural Resource Ecology Laboratory, Colorado State University, Fort Collins, Colorado
}

(Manuscript received 22 July 2019, in final form 12 June 2020)

\begin{abstract}
Many rural communities in the western United States are surrounded by public lands and are dependent on these landscapes for their livelihoods. Climate change threatens to affect land-based livelihoods through both direct impacts and public land agency decision-making in response to impacts. This project was designed to understand how Bureau of Land Management (BLM) permittees, including ranching and recreation-based businesses in Colorado, are vulnerable to both climate change and management responses and how permittees and the BLM are adapting and could adapt to these changes. We conducted 60 interviews in two BLM field offices to gather permittee and agency employees' observations of change, impacts, responses, and suggestions for adaptive actions. Data suggested that permittees are dependent on BLM lands and are sensitive to ecological and management changes and that current management policies and structures are often a constraint to adaptation. Managers and permittees are already seeing synergistic impacts, and the BLM has capacity to facilitate or constrain adaptation actions. Participants suggested increased flexibility at all scales, timelier within-season adjustments, and extension of current collaborative efforts to assist adaptation efforts and reduce impacts to these livelihoods.
\end{abstract}

\section{Introduction}

The western United States is a matrix of land ownership, dominated by public lands (Stowell 2016). These lands are public in part because of their aridity and low production, which made them less appealing for homesteading. Recreation and ranching livelihoods, which

D Denotes content that is immediately available upon publication as open access.

Corresponding author: Corrine Noel Knapp, corrie.knapp@uwyo.edu are the focus of this study, are dependent on these public lands and the ecosystem services they provide. Ecosystem services are the benefits that humans receive from ecosystems, such as pollination, forage, and recreational opportunities (Millennium Ecosystem Assessment Program 2005). Agency decisions made on public lands impact these ecosystem services and therefore the livelihoods and local communities that depend on them. At the same time, these industries are also large contributors to the state economy, respectively contributing $\$ 34.5$ billion (recreation) and $\$ 41$ billion (ranching) (Babcock and Kachur 2014; USDA 2012), and livelihood decisions, even if made 
on adjacent private lands, can impact public lands. Climate change is already shifting the timing, quality, and quantity of these ecosystem services and is projected to continue to influence them into the future (Gonzalez et al. 2018; Gordon et al. 2014; Reidmiller et al. 2018).

The Bureau of Land Management's (BLM) mission involves managing landscapes for multiple uses. In the context of a changing climate, this is a complex task, requiring maintaining ecosystem health while providing and managing ecosystem services to maintain multiple uses. This requires a better understanding of livelihood climate change vulnerabilities, the trade-offs and synergies between ecosystem health and livelihoods, and also between various livelihoods and their demands for ecosystem services. In this paper, we report on interviews conducted to assess vulnerability of land-based livelihoods in two BLM field offices (FOs) in Colorado with the goal of informing strategies for effective management in the context of climate change.

\section{a. Management context}

Federal land management agencies were tasked by the Obama administration with integrating climate change science and related impacts (biophysical and social) into their planning processes (U.S. Department of the Interior 2014; Obama 2009, 2013, 2015). Yet, integration has varied across federal land management agencies, with strong leadership in the National Park Service $(2010,2012)$ and U.S. Forest Service (USFS; USFS 2009) and less guidance from the BLM. A recent review of BLM field-office-level planning documents in Colorado showed minimal to no incorporation of climate change science, impacts, vulnerabilities, or responses (Nave et al. 2020). Recent actions by the current administration have rescinded climate change policies (U.S. Department of the Interior 2017b,a; Trump 2017), despite overwhelming evidence of potential impacts (IPCC 2013). While the current political context makes it doubtful that climate change will become widely integrated into public land planning, FO understanding of vulnerability can assist in making informed decisions. This is especially important given the Department of the Interior's recent priorities, one of which is restoring trust and being a good neighbor (U.S. Department of the Interior 2019).

Even when agencies assess potential impacts and vulnerability, the translation into adaptation strategies is often lacking (Archie et al. 2012; Ellenwood et al. 2012). Documented challenges for adapting to climate change include ambiguous policies, limited resources, political acceptability, and lack of information at relevant scales (Archie et al. 2014; Blades et al. 2016; Kemp et al. 2015; Timberlake and Schultz 2017). Even when information is available at project-level scales, managers often lack confidence in the results of modeled projections (Blades et al. 2016). Challenges of communication across management scales may also hinder development of useful climate change information (Laatsch and Ma 2016). If lack of information at relevant scales is an issue, then qualitative research may help to provide localized information that credible and could help to facilitate creation of viable adaptation strategies (McNeeley et al. 2017a).

Field offices are the local organizational unit for the BLM and directly manage landscapes, and they are supported by regional, state, and national offices. Field office management is guided by a Resource Management Plan (RMP) that is revised and replaced every $10-30$ years after the public review and planning process dictated by the National Environmental Policy Act (NEPA) (BLM 2016). These documents set broad management guidance including land use policies, appropriate uses, and details on the terms of grazing and recreation permits. At the field office level, decisions about timing of permits may shift based on severe weather conditions, but flexibility from RMP guidance is often dependent on local personalities, trusting relationships with permittees, and tolerance for risk. Prior studies suggest a desire from land use permittees for greater management flexibility within and between seasons, and on all levels (RMP, operational, and permitting) (Charnley et al. 2018; Neely et al. 2011; Warziniack et al. 2018). However, this would require additional monitoring, which agencies often do not have the resources or time for (Veblen et al. 2014).

\section{b. Vulnerability of land-based livelihoods}

Vulnerability is a population's exposure to climate hazards (e.g., extreme heat), their sensitivity to harm from those hazards, and their adaptive capacity in the face of existing and future climatic conditions (Adger 2006). The conceptual framework of vulnerability guides our research design and analysis (Turner et al. 2003; Ford and Smit 2004; Adger 2006). Research demonstrates that livelihoods directly dependent on natural systems and the ecosystem services they provide will be vulnerable to climate change (Agrawal and Perrin 2008; Morton 2007). Climate change vulnerability reviews exist for both recreation (Hamilton et al. 2005; Hand and Lawson 2018; Verbos et al. 2018) and ranching (Briske et al. 2015; Joyce et al. 2013; Reeves and Bagne 2016). These reviews demonstrate the importance of consistent access to, and reliable management of, public lands and the ecosystem services they provide, as well as the critical role of water quality, availability, and timing, which can be impacted by climate change. There are also case 
studies on the vulnerability of recreation-based businesses (Hingham and Hall 2005; Richardson and Loomis 2004; Scott et al. 2008) and ranching operations in specific regions (Liu et al. 2014; Wyborn et al. 2015). These place-based studies suggest that the unique context of each ecosystem and human community, the specific patterns of impact, and implications of vulnerability will vary in different locations. For instance, investments in snowmaking at northeastern ski resorts can significantly reduce their vulnerability (Scott et al. 2008), while beliefs about the role of government and the source of climate change in Montana may constrain the effectiveness of government-led adaptation efforts (Yung et al. 2015).

In addition to the immediate impacts and vulnerabilities that land-based livelihoods will experience from climate change, institutional structures (rules, regulations) and specific manager responses can amplify vulnerability. Although the USFS adopted a climate change scorecard to incentivize action, most staff felt limited in their ability to implement adaptation strategies based on ambiguity of concepts, uncertainty, and institutional structures (Timberlake and Schultz 2017). While several recent publications describe challenges to agency implementation of climate change actions, none of them discuss how management actions might impact livelihoods (Archie et al. 2014; Blades et al. 2016; Kemp et al. 2015; Laatsch and Ma 2016).

In this paper, we use qualitative interviews in two Colorado BLM FOs and demonstrate similarities and differences in local vulnerabilities across sectors and cases. The research herein is the first place-based climate change vulnerability assessment on BLMmanaged lands in Colorado. It is also unique because we look at local vulnerabilities arising from both climate and landscape condition as well as from public land decision-making. The goal of this work is to help BLM effectively adapt to climate change in a way that will allow them to both maintain ecosystem health and fulfill their multiple use mandate.

\section{Methods}

This study was framed by the following research questions:

1) How are land-based livelihoods with connections to public lands vulnerable to

(i) changes in climate and landscape condition and

(ii) changes in public land management associated with changing climate and land condition?

2) What are public land agencies and the livelihoods that depend on them doing to adapt to current and future conditions?

\section{a. Research approach and analytical framework}

Our research used a modified grounded theory approach. Grounded theory is an inductive approach where concepts and theory emerge from qualitative data to better mirror the way participants perceive and experience reality (Glaser and Straus 1967). Our modified approach is a compromise between inductive and deductive, where existing theory (see analytical framework below) helps to guide the coding process (Bryant and Charmaz 2010). This hybrid approach was justified by the context-dependent nature of adaptation.

Our analytic framework is based on considering vulnerability as a function of exposure, sensitivity, and adaptive capacity (see Turner et al. 2003; Ford and Smit 2004). We define exposure of social systems as "the character, magnitude, and rate of changes to which a human community is exposed to climate changes" (McNeeley et al. 2017b, p. 109). Exposures are external to the population, arising from warming temperatures, extreme events, or other sources of stress originating from climate and weather phenomena. Sensitivity is "the degree to which a human community is susceptible to harm or likely to be affected by climate changes and/or decision-making on public lands" (McNeeley et al. 2017b, p. 109). Sensitivity is internal, and can be heightened by factors, ranging from financial reserves (e.g., due to poverty), dependence upon a climate sensitive livelihood (such as cold-water recreational fishing), or regional and global connections (e.g., cattle markets). Adaptive capacity is "the ability of human communities to generate and apply new knowledge, make decisions, and act collectively to reduce climate exposures and modify sensitivities, thus reducing overall vulnerability" (McNeeley et al. 2017b, p. 109). For instance, a recreation business that is diversified across seasons might have more adaptive capacity than one that relies on a single season (Knapp 2011). Social, political, and regulatory barriers can constrain adaptive capacity, and are therefore important to understand to implement adaptation strategies (Bierbaum et al. 2013; McNeeley 2012; Moser and Ekstrom 2010).

\section{b. Data collection}

Interviews were carried out in two FOs: the Little Snake FO (LSFO) and Gunnison FO (GFO) (Fig. 1). We chose these FOs because of the heavy dependence of these regions on public lands, representativeness of these regions to FOs across the state, and ongoing research in these regions. Both FOs have vibrant tourism economies, as well as thriving agricultural communities, with nearly half of all jobs in both regions being 


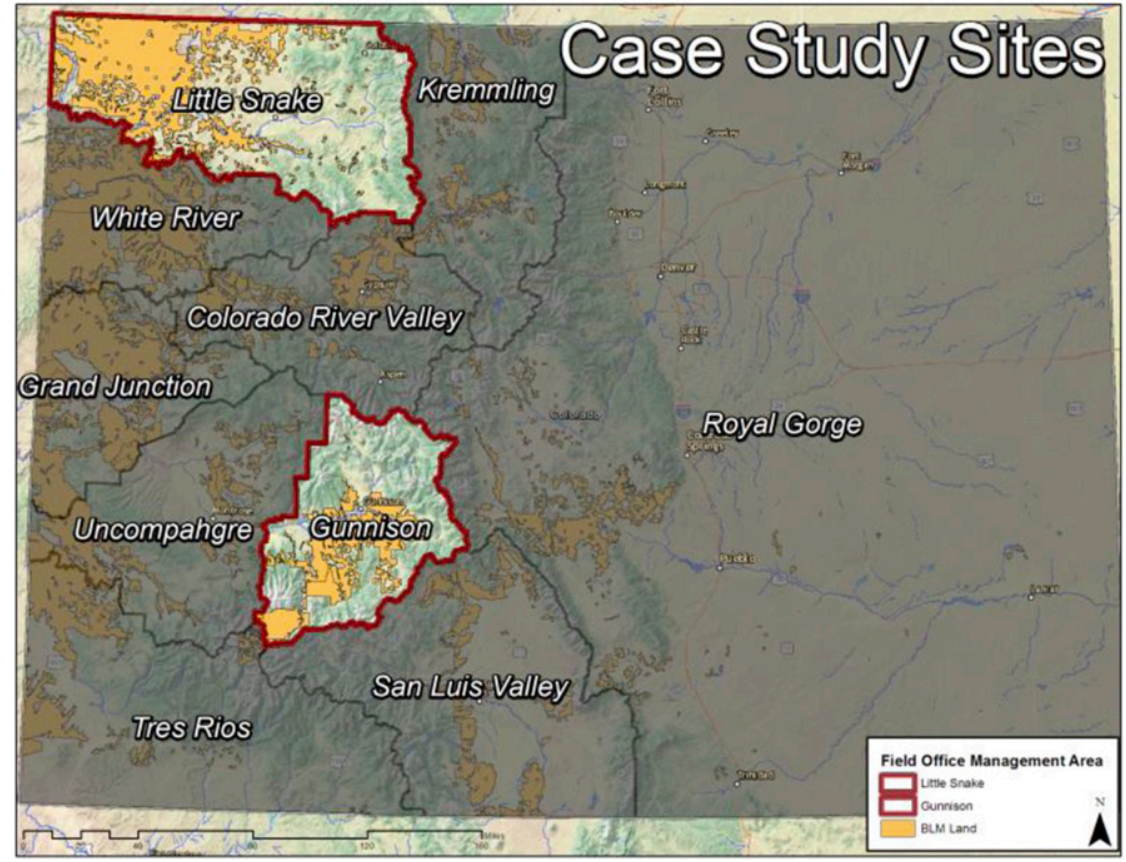

FIG. 1. Map of BLM field offices included in this study.

dependent on natural resources and tourism. Key similarities and differences are summarized in Table 1.

We used publicly available information provided by the BLM FO website, the Rangeland Administration System, and State of Colorado BLM records to purposefully sample potential participants. Selection was based on their representativeness of the user group. For example, we selected ranchers based on the type (cow/calf, sheep, and steers) and size (acreage of public leases) of their operation and relative dependence on public lands [number of permitted animal unit months (AUMs)]. For the recreation outfitters, we considered types of businesses (e.g., rafting, guiding, hunting, and fishing), size (number of employees), and operation within boundaries of BLM FO jurisdiction. We also used snowball sampling of BLM employees to identify other potential participants to broaden the range of perspectives. Range- and recreation-focused BLM staff were also identified. We reached out to potential participants with a letter and follow-up telephone call to schedule interviews. We contacted a total of 86 participants and were able to conduct interviews with 60

We conducted qualitative, semistructured interviews $(n=60)$ with BLM staff $(n=15)$, livestock ranchers (ranchers; $n=24$ ), and recreation outfitters (outfitters; $n=21$ ). Qualitative, semistructured interviews allow the flexibility and responsiveness to gather context-specific data from participants, and they are a preferred method of data collection when the questions are exploratory (Ritchie 2013). Interviews were conducted in person or over the telephone and lasted between $30 \mathrm{~min}$ and $1.5 \mathrm{~h}$. Interview questions documented local experiences of exposure, sensitivity, and adaptive capacity (defined in section 2 a above). For example, we asked participants how local changes in climate and weather were impacting the resources they depend on (exposure), how participants were impacted by these changes (sensitivity), what types of management decisions or actions inhibit response (adaptive capacity), and what local managers and users are doing to respond to climate variability and change (adaptive capacity) (see appendixes $\mathrm{A}$ and $\mathrm{B})$.

\section{c. Data analysis}

Interviews were audio recorded, transcribed, and then analyzed using qualitative data analysis software, including both NVivo and MaxQDA. Our design included both deductive (concepts related to our analytical framework of vulnerability) and inductive (emergent themes related to research questions) elements. This modified grounded theory allowed us to assess how participants responses mapped to vulnerability concepts and track emergent concepts and themes across interviews that related to our research questions. This approach to coding is appropriate for exploratory studies and allows participants' ideas and concepts to structure ongoing analysis (Bryman 2016). Analysis 
TABLE 1. Comparison of attributes between Little Snake Field Office and Gunnison Field Office. See McNeeley et al. (2017a) for additional information.

\begin{tabular}{lcc}
\hline \hline & $\begin{array}{c}\text { Little Snake } \\
\text { Field Office }\end{array}$ & $\begin{array}{c}\text { Gunnison } \\
\text { Field Office }\end{array}$ \\
\hline Private land (acres) & $1752216(41 \%)$ & $439529(18 \%)$ \\
BLM (acres) & $1339941(32 \%)$ & $613335(25 \%)$ \\
Other public lands (acres) & $1126712(27 \%)$ & $1444333(57 \%)$ \\
Total land base (acres) $^{\text {Permitted AUMs }}{ }^{\mathrm{a}}$ & 4218950 & 2497197 \\
No. of grazing permits $^{\mathrm{a}}$ & 148568 & 42966 \\
Special recreation permits $^{\mathrm{b}}$ & 337 & 118 \\
Percent dependence on & 53 & 67 \\
$\quad$ natural resources and & $49 \%$ & $48 \%$ \\
$\quad$ tourism jobs & & \\
No. of interviews & & 32 \\
BLM staff & 28 & 8 \\
Grazing permittees & 7 & 10 \\
Special recreation & 10 & - \\
$\quad$ permittees & 9 & \\
Other (e.g., local hotel & & \\
$\quad$ operators) & 2 & \\
\hline
\end{tabular}

a June 2016 Rangeland Administration System Data (https:// reports.blm.gov/reports/RAS/).

${ }^{\mathrm{b}}$ Colorado BLM Recreation Permit Data (compiled 2016 from Colorado BLM staff).

c 2016 County Business Patterns, U.S. Census Bureau (https:// www.census.gov/programs-surveys/cbp.html).

involved an iterative process of exploring qualitative passages related to each theme, summarizing those passages, and then returning to the qualitative data to gauge the accuracy of our original assessments (Creswell 2014; Ritchie 2013).

\section{Results}

The purpose of this study was to understand 1) how public-land-dependent livelihoods are vulnerable to climate/landscape condition and changes in agency decision-making and 2) what respondents are doing to adapt.

\section{a. Shared exposures and differential ecological impacts}

All project interviewees reported observed changes and impacts related to climate and weather. Exposures were similar across sectors but concerns about ecological impacts were different (Table 2). Across both FOs, drought $(2002 ; 2012)$ was the primary climaterelated exposure. As one rancher stated, "Those extreme droughts are very hard to swallow and to manage through. We've done it twice and I hope I don't have to ever do it again." Participants also described shifts in the quality of winters (warmer, less intense, and shorter) with reduced snowpack and an earlier onset of spring, which leads to earlier and more intense runoff. They also described warmer maximum summer temperatures and more intense rainfall events. Participants also observed increased climate variability. As one BLM employee stated, "Wild fluctuations in weather, like big rain events or a huge wet season can definitely give us some challenges."

All permittees shared concern over increased wildfire, vegetation responses, wildlife responses, and timing and intensity of precipitation. Increased wildfire was a concern in both FOs, but with more immediate

TABLE 2. Shared exposures and differential environmental impact for grazing and recreation permittees. When the two groups of permittees share an exposure or a concern, their respective columns are merged and the concern/exposure is centered.

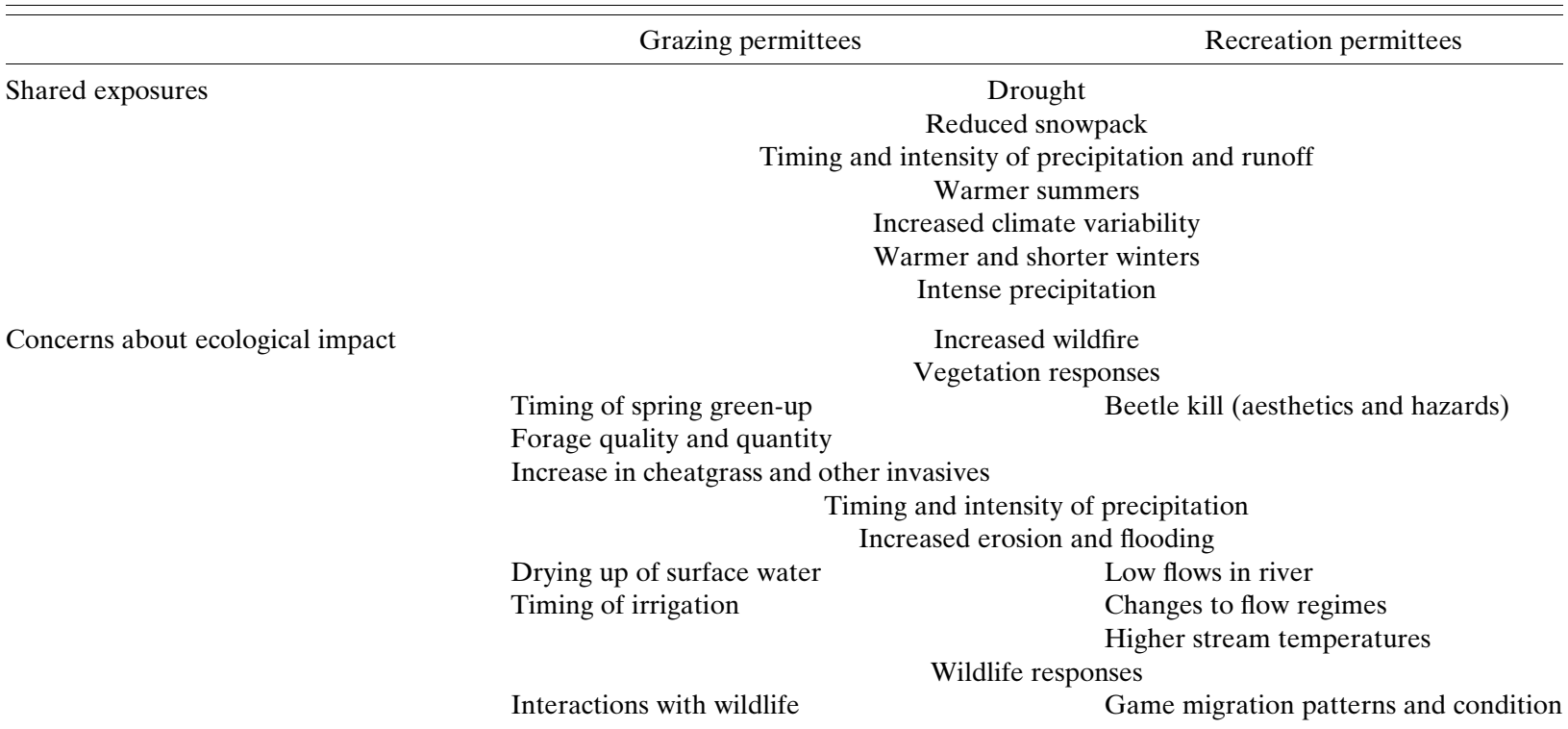


TABLE 3. Sensitivities to ecosystem services and agency decision-making shared by land-based livelihoods and unique to ranching and recreation-based business participants.

\begin{tabular}{|c|c|c|}
\hline & Dependence on ecosystem services and timing & $\begin{array}{l}\text { Dependence on public land } \\
\text { decision-making }\end{array}$ \\
\hline Shared sensitivities & Timing and availability of water resources & $\begin{array}{l}\text { High dependence on public lands } \\
\text { Inflexible management structure } \\
\text { Limited cross-boundary collaboration } \\
\text { Synergistic sensitivities } \\
\text { Agency uncertainty }\end{array}$ \\
\hline Grazing permittee sensitivities & $\begin{array}{l}\text { Forage quality and timing } \\
\text { Weather events and influence on cattle health, nutrition } \\
\text { demands, and disease } \\
\text { Cultural values of public lands } \\
\text { Changes to fire regime }\end{array}$ & $\begin{array}{l}\text { Slow process for range improvements } \\
\text { Potential and actual limits on grazing }\end{array}$ \\
\hline Recreation permittee sensitivities & $\begin{array}{l}\text { Seasonality mismatch } \\
\text { Weather events and recreation infrastructure } \\
\text { Changed aesthetics }\end{array}$ & $\begin{array}{l}\text { Limited recreation permits } \\
\text { Lottery system for fishing. }\end{array}$ \\
\hline
\end{tabular}

concern in LSFO and future concern in GFO due to a rapidly growing spruce beetle epidemic and potential stand-replacing fires. While permittees were all concerned about vegetation responses, grazing permittees were more concerned with timing of spring green-up, forage quality and quantity, and increased cheatgrass. Recreation permittees were more concerned with beetle kill and the resulting aesthetics and hazards. In terms of wildlife, grazing permittees worried about competition with domestic livestock and hunting guides were concerned with both shifts in game migration patterns and game condition. Both permittees were concerned with risks for increased flooding and erosion due to the timing and intensity of runoff. Grazing permittees were concerned about timing for irrigation and surface water, and recreation participants were concerned with low flows in rivers, which impacted rafting seasons and cold-water fisheries.

\section{b. Sensitivity}

In this section we will address sensitivities related to ecosystem services and timing and management decision-making. Results are summarized in Table 3.

\section{1) DEPENDENCE ON ECOSYSTEM SERVICES AND TIMING}

Land-based livelihoods are dependent on both ecosystem services provided by public lands and the timing of these services, which are increasingly unpredictable. As one BLM employee stated, "One group that's pretty dead set that things aren't like they used to be is these oldtimers. Almost to a man, they will tell you things are different, and don't really get into the whys." Concerns about mismatch between livelihood activities and timing of ecosystem services is common across FOs and sectors. One example of this mismatch is the timing of irrigation water availability for hay production, or rafting visitation timing and river flows. Managing these mismatches is often dependent on agency decision-making and can increase sensitivity (e.g., timing of grazing permits and forage availability). Since we had similar findings across FOs, we will focus on differences across sectors, highlighting when there were FO differences.

\section{(i) Ranching}

Within the ranching sector, there were consistent types of dependence on ecosystem services across both FOs. Ranchers were dependent on the timing and quantity of water, timing, quality and amount of forage, weather events as they impact cattle health, cultural values of public lands, and the frequency and intensity of fire. Dependence of water resources for ranchers focuses primarily on the timing of runoff available for irrigation of hay, the timing and amount of precipitation for forage growth, and the availability of surface water for the distribution of cattle. Both FOs are described already as arid, so any shift in precipitation can be impactful. The timing and intensity of winter storms, and the frequency of rain on snow and dust on snow events influence the timing of runoff for irrigation. Ranchers need runoff to correspond to the beginning of the growing season so they can flood their hay meadows. Precipitation is also important in the spring and during the summer monsoon for hay growth. Cattle ranchers rely on surface water within pastures to utilize forage resources and distribute cattle in a sustainable manner. If water is not available, cattle will overuse areas in close proximity. Lack of surface water during the mid-late summer can lead to extra labor hauling water, more investment in wells, poor distribution, or the inability to utilize forage. 
Forage availability and quality are linked to precipitation and runoff (as described above) but are also interconnected with temperature/precipitation influencing range readiness, wildlife competition, and the spread of invasive species. Parts of both FOs were described by BLM employees as degraded and sensitive to grazing pressure during drought. Ranchers also described voluntary nonuse of permits in low production years or years with resource concerns. Ranchers described how warmer temperatures can lead to a competitive advantage for invasive species such as cheatgrass, which in turn can lower overall forage quality and influence fire behavior. They also discussed how lower quantity or quality of forage resources can have impacts on cattle gains and condition as well as ecological health.

Ranchers also talked about how changes in weather can influence cattle health, nutrition demands, and disease. One positive is winter temperature increase can lower cattle feed requirements. Wetter springs, however, can influence disease in cattle, especially during calving. As one rancher described,

We had some severe storms. There was significant impact on livestock health that way because of the newborns, the stress. When we had those real wet springs like that, when we're actually calving, there's a high incidence of respiratory issues, just poor health all the way through.

In both field offices, ranchers described their connections to the landscapes they steward as well as their livelihoods. Public lands provide cultural services around the maintenance of human-land connections and land-based livelihoods, resulting in in stewardship behavior. As one rancher stated,

So rather than, than taking the chance and roll the dice and, and stress[ing] that ground, we held out, grazed it less, tried to practice proper management. So that in the future we come back the next year and we have good grazing again.

In the LSFO management area, there was concern about recent large fires that have the potential to shift sagebrush to cheatgrass. Change in fire cycles could also impact forage availability and displace herds. In the GFO, there have been fewer fires, but they are a growing concern in dry years. For both FOs, fire imposes a 2-yr hiatus on public land grazing, which impacts grazing permittees by limiting access to burned areas.

\section{(ii) Recreation}

In the recreation sector, there are high levels of variation in ecosystem services dependence. Respondents described concerns with the narrow windows of operation and mismatch between the peak season for the activity and the peak season for tourism. While this sensitivity is primarily ecological in nature-shifting in timing of ecosystem services - it can be compounded by management practices that are inflexible. Although tourism seasons may be able to shift, school breaks and habitual tourist patterns might constrain the ability of recreationists to adapt to changing weather-related events and issues. Across recreation-based businesses, outfitters described concerns about threats to roads and trails from shifts in the intensity and timing of precipitation, which could have impacts on erosion as well as water quality in adjacent streams.

In the following sections, we will specifically address the sensitivities of four major recreation sectors. First, hunting guides rely on the abundance, distribution, and type of wildlife in a management area. Wildlife distribution is influenced by temperature, timing of snowfall events, disturbance regimes (fires and floods), and forage availability. Guides described how warmer winters are changing big game distribution. New vegetation following large wildfires attract big game, providing a likely location for spotting game animals who come to graze in the open spaces. However, decreased forage availability and quality can lead to a decline in larger trophy elk, which is a challenge for guides in LSFO management area who make most of their income off these types of animals. Guides also described how in drought conditions mule deer may fare better, shifting the amount of income guides make from different big game species. Guides talked about how early snowstorms can benefit hunter success through easier tracking but often drive big game to private lands (lower elevation).

Second, we examine the water-based-recreation sector, which includes rafting and fishing guides. These businesses are concerned with changes in the timing, quantity, and quality of streamflow. For a successful season, rafting and fishing operators need adequate snowpack in the winter, gradual and sustained spring runoff, and summer monsoonal rains that align with peak visitation (generally from late June to mid-August). Fishing guides described how increasing temperatures negatively affect stream temperature and water level for sensitive fish species, often forcing curtailing or ceasing of fishing on certain river stretches if stream temperatures are too high. As one fishing guide stated,

If the water's muddy and high in July people aren't coming out then our season doesn't start 'til the next month. You know, it just pushes us back and gives us a shorter window of time to get all those trips and make as much money as we can in the summer.

Several guides in this sector were also concerned about the shifting aesthetics of forests and near-stream habitats due to wildfire and beetle kill as those impacts may affect visitation patterns and therefore business income. 
Third is the downhill-ski-area sector. Concerns in this sector were high across both FOs, with Crested Butte in the GFO area and Steamboat upstream of the LSFO area. Both ski areas were described as foundational economic drivers that could have large impacts on the overall tourism economy. The primary ecosystem services that ski areas rely on are consistent snowpack during the winter, cold temperatures to maintain snowpack and minimize rain-on-snow events, and lack of dust-on-snow events. This sector expressed sensitivity to weather changes, and other recreationbased businesses expressed concern about a decline in tourists drawn to the area for skiing.

The fourth sector of interest is land-based recreation. This sector includes hiking, biking, horseback riding, camping, backpacking, and wildflower/bird/wildlife viewing, which are dependent on ecosystem services including primarily aesthetics and weather predictability. Several businesses described concerns about postbeetle and postfire aesthetics and the resulting impact on visitor use of impacted areas. Several participants mentioned a displacement in recreation pressure after the High Divide Fire near Lake City. Weather predictability is important for recreation events such as wildflower festivals, races, and other outdoor events. In addition, BLM employees cited concerns about hazard trees in areas around popular trails and campgrounds, which could impact the safety of recreators.

2) DEPENDENCE ON PUBLIC LANDS AND AGENCY DECISION-MAKING

\section{(i) Dependence on public lands}

Both FO counties have high percentages of public lands (see Table 1), and ranching and recreation livelihoods rely on access to public lands. For ranchers, variations in dependence had to do with private land ownership or leasing, size of public lands parcels, and relative dependence on USFS versus BLM lands. Most permittees rely on a matrix of landscape ownership (private, BLM, and USFS). Ranching permittees described how there were trade-offs between use of public and private lands. As one rancher said,

We have these huge riparian corridors throughout the valley. And those are all private lands. And that's where those cattle end up when you delay [access to public lands]. So granted you might be reducing your impact on that one [public] piece, but you are changing the impact on every other piece of that whole system.

Many ranching participants stated that their operations would not be feasible without BLM public lands because of the necessity to grow hay on their private lands, mainly riparian floodplains. BLM lands provide a valuable resource in the spring before operators could move to higher elevation USFS permits.

Recreation special use permittees described how they relied on a range of permits from private landowners, BLM, USFS, and Colorado Parks and Wildlife. The majority of recreation permittees did not have any private land resources and depended entirely on permits on private or public land parcels. In the Gunnison area, we found little overlap between ranching and recreation permittees, while in the LSFO area there was a large amount of overlap, with many ranchers also operating as hunting guides/outfitters.

\section{(ii) Current agency decision-making and manage-} ment structure

BLM employees across FOs expressed awareness of the impact of agency decision-making on permitted livelihoods. As one BLM employee stated,

We have to look at changing numbers, dates, time, all that duration of grazing based on what the forage is. And that's our biggest direct impact that we see managing BLM is that these users are then, it's their [permittee's] livelihood.

The most typical management decisions related to weather variability by BLM range staff include deferment, curtailments, loss of permits, or use restrictions in response to seasonal weather or wildlife considerations. Neither FO has had to cancel permits, although they considered it in drought years (2002; 2012). Both have used short deferrals or in rare cases cattle reductions in response to a lack of range readiness because of drought or cold/wet springs. On the recreation side, there have been few deferments or curtailments in use, mostly in response to fire, erosion, or other resource concerns. Typically implemented as a road and/or trail closure, these decisions may impact the ability of people to access recreation use areas. While few management decisions have influenced permittees thus far, the structure of management leads to sensitivity to climate changes.

\section{(iii) Inflexible management structures}

Both ranching and recreation permittees cited lack of flexibility in existing management as a factor increasing permittee sensitivity to climate change. RMPs stipulate typical use of permits and how managers can amend permits based on drought, weather conditions, or significant degradation of resources. Grazing permittees described that guidelines in the RMP, as well as procedural hurdles in NEPA, make it challenging to shift timing and amount of use to yearly and seasonal conditions. Ranchers described how shifts more commonly 
restricted producers rather than offering them opportunities. As one rancher described,

We've been held off on the drought. And we've been held off on a wet year. And never have we ever gone out early. So that's one of the sticky points of the management that I see, not really conforming to what's actually happening out there with the grasses and the ground.

For those in the LSFO, they saw the possibility to use grazing to control cheatgrass, but this would require more flexibility with timing of grazing. Grazing permittees wanted to be allowed to graze early if conditions permitted, switch season of use based on weather conditions, or adjust stocking rate to meet forage production in productive years. They described how they would also be more open to restrictions if they were also allowed to take advantage of opportunities.

Recreation permittees also described how restrictions on season and area of use challenge their ability to respond to within-season weather events. As one permittee stated,

Some of the BLM permits are only, we only have it for 3 months, so that's constricting because if something happens [weather related] either before or after that makes it so that we need to go there, we can't.

In addition, recreation permittees described weatherrelated factors limiting allocated use days. For instance, fishery restrictions during drought could lead to nonuse of permits. In a few cases, permittees described how nonuse could lead to cuts in future allocations. Although some level of flexibility is possible outside of the RMPs, this often depends on the leadership style of FO Managers as well as level of trust with permittees.

\section{(iv) Limited cross-agency collaboration}

Both grazing and recreation permittees described the need for better coordination and communication between USFS and the BLM to understand permittee dependence and timing issues across agencies. As one grazing permittee stated,

Our big concern is ... the amount of time we can run the BLM permit before we can go to some of the forest permits. Some of the earliest forest permits are the 15th of June so we have to time our use of the BLM permit to where we don't run out of feed or use the resource before we go to the forest.

Recreation permittees also spoke about dependence on permits from multiple agencies who do not regularly communicate with one another. For instance, fishing guides are typically dependent on permits from Colorado Parks and Wildlife, the BLM, and the USFS. Permittees need to better understand their options across a landscape to adapt to shifting conditions.

\section{(v) Synergistic sensitivities}

These weather-related factors were described as compounding to endangered species management (both offices), wild horse management (LSFO), and multiple use management (primarily GFO). Both types of permittees described how endangered species management, related to greater sage grouse in LSFO and Gunnison sage grouse in GFO, had created sensitivities related to closures and restrictions, with concerns that these might increase in drought conditions. As one BLM employee stated "Once [the USFWS] designates that critical habitat, that puts a whole host of, of restrictions on the uses of that land." In LSFO, grazing permittees discussed how current wild horse numbers and management strained the ability to utilize resources, which could be extenuated with climate change.

In the GFO, grazing permittees spoke about the need to manage across ranching and recreation sectors to avoid multiple use conflicts. Recreation use is increasing, which creates resource impacts and new challenges for management (leaving gates open, recreation harassment of livestock). As one rancher remarked,

[Recreationists have a] complete disregard for the gates, for the roads, for the fences, for the cattle. And it's becoming a really big problem. In fact, if you were going to ask me what my biggest problem on federal land is, I would tell you recreation.

\section{(vi) Agency uncertainty about future conditions}

BLM employees described the challenge of planning for restoration efforts (e.g., timing of seeding because of increased variability, which influenced their ability to effectively manage the ecosystems that permittees depend on. Several BLM employees spoke about their desire for more information on a local scale to help them better adapt and plan for climate change [see section 3c(4)].

\section{(vii) Limited recreation permits}

Several recreation permittees described how recreation areas were at capacity in terms of allocations. Overall competition for permits may increase climate change sensitivity for recreation-based businesses since alternative permit locations are limited. For instance, the lottery systems for high-demand fishing areas limit year-to-year security for fishing guides. This may also encourage permittees to continue to use permits even when conditions could lead to resource degradation. One example of this described in 
TABLE 4. Current responses to climate change and perceptions of adaptive capacity and factors needed to increase adaptive capacity. The factor categories "additional flexibility" and "cross-boundary coordination" are centered to indicate that they are shared by both groups of permittees.

\begin{tabular}{|c|c|c|c|}
\hline & BLM employees & Grazing permittees & Special recreation permittees \\
\hline \multirow[t]{5}{*}{$\begin{array}{l}\text { Current adaptive actions and } \\
\text { perceptions }\end{array}$} & $\begin{array}{l}\text { Commitment to collaborative } \\
\text { partnerships }\end{array}$ & $\begin{array}{l}\text { Extensive experience dealing } \\
\text { with weather variability }\end{array}$ & $\begin{array}{l}\text { Variation in perceived adaptive } \\
\text { capacity }\end{array}$ \\
\hline & $\begin{array}{l}\text { Current responses to bark } \\
\text { beetle, fire, and wild horse } \\
\text { management }\end{array}$ & Diverse suite of responses & $\begin{array}{l}\text { Temporal diversification of } \\
\text { livelihood activities }\end{array}$ \\
\hline & & $\begin{array}{l}\text { Inherent trade-offs in current } \\
\text { responses }\end{array}$ & $\begin{array}{l}\text { Shifts in recreational } \\
\text { experiences offered }\end{array}$ \\
\hline & & Livelihood diversification & $\begin{array}{l}\text { Spatial diversification of } \\
\text { recreation locations. }\end{array}$ \\
\hline & & $\begin{array}{l}\text { Relationships of trust with } \\
\text { agencies }\end{array}$ & \\
\hline \multirow{5}{*}{$\begin{array}{l}\text { Factors needed for adaptive } \\
\text { capacity }\end{array}$} & Better information to deal with & \multicolumn{2}{|c|}{ Additional flexibility } \\
\hline & & Flexible turnout dates & $\begin{array}{l}\text { Ability to adjust permits "in } \\
\text { season" }\end{array}$ \\
\hline & & $\begin{array}{l}\text { Strong relationships and trust } \\
\text { between BLM staff and } \\
\text { land users }\end{array}$ & Ability to carry over use days \\
\hline & & Cross-bounc & $\begin{array}{l}\text { Flexible Colorado Parks and } \\
\text { Wildlife dates/tag numbers } \\
\text { y coordination }\end{array}$ \\
\hline & & \multicolumn{2}{|c|}{$\begin{array}{l}\text { Cross-boundary coordination } \\
\text { provements } \\
\text { water }\end{array}$} \\
\hline
\end{tabular}

interviews was continuing guided mountain bike tours on muddy trails.

\section{(viii) Slow process for range improvements}

Ranching permittees across FOs spoke about slow processes for range improvements such as water developments. Water developments help to utilize pastures, improve distribution, assist wildlife populations, and protect riparian areas. Permittees spoke of long waits for required permits, which impeded responsive actions to deal with resource concerns. As one rancher explained,

I've talked to my range manager about possibly putting in some more holding ponds on some of our permits. But the backlog, X said it would be three to four years before we could even get to look at it.

\section{c. Adaptive capacity, responses, and barriers}

In this section, we will present current responses, perceptions of adaptive capacity, and desires for future actions. These factors are summarized in Table 4.

\section{1) CurRent BLM RESPONSES AND PERCEPTIONS}

The BLM built adaptive capacity through collaborative partnerships, which build trust, work across boundaries, and develop working relationships between partners. The Gunnison Climate Change Working Group, for example, has helped agencies come together to learn about climate changes, consider how changes might influence management and planning, and work across boundaries on landscape-scale coordination. As one agency employee related, "[It's] been critical for us to be involved with that, because we wouldn't be doing climate change adaption, be talking climate change, if it wasn't for that working group." In both FOs, cross-boundary efforts for Gunnison and greater sage grouse have increased coordination between agencies and helped to coordinate grazing plans across boundaries. Respondents felt these efforts could be expanded to reduce sensitivities and build adaptive capacity by leveraging resources, allowing more efficient use of resources, and navigating multiple use conflicts.

The BLM adapted management to changes in fire and spruce bark beetle, including expanding hazardous tree removal for human safety. In LSFO, managers have increased attention to, and planning for, the wildfire season and managing wild horse population numbers to curb degradation of natural resources. In LSFO, letters were sent to permittees during the 2012 drought, warning of potential curtailments. While they were not needed due to voluntary permittee curtailments, the letters signified a willingness to shift management based on environmental conditions. 


\section{2) Current RANChing PERMitTeEs ResPonses AND PERCEPTIONS}

Ranching permittees expressed high levels of experience dealing with climate extremes, and overall comfort with adapting to within and across year variation. The most common responses to observed changes included buying feed, selling cattle, and leasing private lands. Buying feed was considered a good short-term coping mechanism for drought, but it can be cost-prohibitive especially if the drought has increased feed costs. One BLM employee described responses to the 2012 drought:

They're selling cows. They're moving cows. They're having to supplement feed at home. In 2012 that's what most did. They had to keep them home on their meadow and feed them hay. And you couldn't find the hay cheap so they're shipping hay from Texas.

Selling cattle to prevent resource degradation was commonly practiced, but it was often seen as maladaptive since sales reduced context-adapted herd genetics. Leasing private lands was also pursued when needed, but such leases were often limited, competitive, and costly.

Ranchers also invested in water developments on public lands and/or hauled water when surface water was limited. Often water developments were costly and only undertaken by more wealthy operators. Some ranchers described leveraging resources from federal cost-share programs, but others were reticent to take federal money. Water hauling was described as sometimes necessary if surface water were unavailable to utilize pastures that would otherwise be inaccessible.

Less common adaptations included adopting rotational grazing schemes (both FOs), voluntary curtailments (both FOs), livelihood diversification (both FOs), and, for those with high levels of trust, working with local field staff to adjust and adapt to weather conditions within a season (both FOs). Rotational grazing schemes, where permittees use fence and/or riders to move cattle regularly, were described as a way of improving management and building resilience. In the LSFO, letters were sent during the 2012 drought warning of potential curtailments, but by the time permittees received them, most had already voluntarily cut back numbers. This action was taken to maintain the health of rangelands, so that permittees can continue to return to them.

Many permittees in LSFO have diversified to take advantage of the opportunity to sell hunting licenses through the Ranching for Wildlife program (Colorado Parks and Wildlife 2019). Ranchers in the GFO described how diversity of income streams (often a partner with an off-ranch job) helped to make their operations more resilient. Finally, several ranchers described how they have been given greater flexibility due to long-term trusting relationships with agency employees. As one grazing permittee stated, "Sometimes it is June 15th that we go out (on BLM permits) ... but it could be May 30th ... When it's ready, we'll go. They are trusting us now. It's because we're working with them." Grazing permittees across FOs recognized the importance of relationship building even if they currently did not have relationships of trust with agency employees.

\section{3) CURRENT RECREATION PERMITTEE RESPONSES AND PERCEPTIONS}

Some recreational permittees, primarily hunting guides, were perceived as more adaptive than others. As one BLM employee remarked, "Most of the guides that we have in Gunnison know how to kill elk or deer. They know how to go up and get game. So most of those guys are successful no matter what the conditions are." Their success is tied to their ability to adapt to changing conditions.

Recreation permittees have responded to climate change impacts by diversifying activities, changing recreational experiences, and accessing more and different types of land for recreational activities. Several recreation-based businesses described how they have seized money-making opportunities throughout the year, which has resulted in diversified businesses with dependence on multiple seasons and different ecosystem services. River guides utilized different boats and altered the type of trips (walk-wade instead of float) depending on river levels. Fishing guides described switching locations when possible based on conditions. Nordic skiers have begun to construct trails on private lands to begin grooming before trails on public lands reach the 2 -ft minimum for grooming.

\section{4) AdAPTIVE CAPACITY NEEDS AND ASSOCIATED BARRIERS}

Permittees expressed three primary desired changes in BLM management to help them to adapt to the observed changes including 1) greater flexibility, 2) timelier within-season range improvements, and 3 ) increased collaboration on all levels. BLM employees also suggested better information to assist with dealing with uncertainty.

As discussed in the sensitivity section, both grazing and recreation permittees desired more flexibility with their permits. Grazing permittees wanted permits that better matched ecological conditions (timing and intensity) and recreation permittees wanted ability to carryover permits, adjust permits in season and shift timing of Colorado Parks and Wildlife tags to shifts in wildlife. Grazing permittees talked about how building 
relationships of trust would assist in allowing this flexibility. While flexibility was recognized by BLM staff as something that would be useful to permittees to adapt to climate change, it was common to hear concerns about constraints. The same constraints often applied to timelier range improvements, which would help ranchers manage pasture health and respond to drought conditions.

The first constraint that was often discussed by managers were existing regulations such as NEPA. NEPA is a procedural statute that ensures environmental impacts of proposed actions are considered in decisionmaking and informs the public of proposed action and potential environmental impacts, which is intended to provide transparency and the opportunity for the public to challenge and inform decision-making on public lands. While useful and needed for decision-making, the process is time-consuming and difficult to reconcile with sudden, and often uncertain, stressors to which ranchers and outfitters might be exposed to. A backlog of projects and workloads on staff also makes it difficult to amend NEPA documents, such as RMPs, in a timely fashion, as mentioned by on BLM manager,

We're always constrained by what we thought up during the NEPA process. .... if we need to do something and we're six or seven years into permit, we didn't think about it back then when we were doing the [environmental assessment], we've got to go back to the drawing board, and we can't always do that, just because of the volume of our workload.

NEPA was perceived to restrict inter and intra-annual flexibility by requiring advance planning on land management activities.

Potential solutions to this constraint include using adaptive management and/or hiring consultants. Managers discussed the utility of incorporating adaptive management into NEPA documents, including RMPs, so that flexibility is built in. As one BLM employee stated, "Try to build in adaptive management, or at least flexibility to where you don't have to do a plan amendment every time you want to do something that you didn't foresee." Several suggested integrating if/then statements or thresholds to shift management based on current conditions. Another barrier BLM employees discussed was increased monitoring demands of an adaptive management approach to confirm that shifts in management were not having a negative impact on resources. They described an increased need for monitoring, but no resources to complete it. As one BLM employee noted,

in our NEPA documents we have to have preset dates on when we're going to allow [cattle] to go out. And so adaptive management can play into those roles on saying, 'Well, on years that it's warmer out, we could or, or plants are ready, we could allow three days early.' But that takes monitoring to do.

A second solution that was offered by permittees was hiring consultants to assist with monitoring or NEPA process requirements. While hiring consultants might speed up the process, costs might make it only available to wealthier operators.

A third solution was increased collaboration and communication, which were desired by BLM employees and permittees, with the major constraint being the time and resources needed. Collaboration was described as necessary for managing complex and dynamic problems that play out over heterogeneous landscapes with multiple landowners and multiple uses. Existing efforts [see 3c(1)], have inspired both communities to consider what might be accomplished through collaborative partnerships.

BLM employees suggested a variety of possible lines of inquiry that could be of use for building adaptive capacity and decreasing uncertainty. In both FOs, staff described a need for local climate data analysis and modeling capacity to understand local impacts and change in precipitation regimes. As discussed above, limited monitoring capacity was also highlighted as a confounding factor in attempts to make scientifically sound and adaptive decisions. Here, some staff expressed an interest in various technological solutions to this problem-for example, drones, networked cameras, and monitoring stations. Several BLM staff members also noted that a clearer understanding of culture and community context as being potentially helpful in future planning and training processes. These interviewees suggested a need for better social science on how to communicate with, understand, and work alongside the variety of public land users BLM employees encounter, as these populations are also changing in dynamic ways.

\section{Discussion}

We show that rural western economies are dependent on the timing and amount of ecosystem services provided by public lands, suggesting that in the context of climate change agencies need to adopt a more flexible and collaborative approach to land management to avoid impacts to these livelihoods. People in land-based livelihoods are vulnerable to the direct impacts of climate change, which can be exacerbated by management responses to climate change. This study shows that agencies with multiple use mandates will likely see synergistic and cumulative responses to climate change and therefore should be proactive and adaptive in planning for it. 
Finally, public land managers have significant influence in terms of encouraging or dissuading long-term adaptation to climate change given the vast landscapes they manage.

Rural communities surrounded by public lands benefit from, and are often dependent on, these lands. Counties with higher levels of protected public lands have been shown to have higher per capita income than counties with lower amounts of protected lands (Rasker et al. 2013). Many livestock ranchers across the western United States depend on public lands for forage resources (Rimbey et al. 2015) and trends suggest that demand for recreation experiences on public lands is increasing (White and Stynes 2008). There are high levels of dependence on public lands in Colorado, with variability in type of use and level of dependence by FO (McNeeley et al. 2017a).

One of the current U.S. Department of the Interior (DOI) priorities is to build trust and be a good neighbor (U.S. Department of the Interior 2019). In the western United States, BLM "neighbors" are those whose livelihoods rely on public lands. These neighbors often also provide benefits to public land agencies, including maintenance of intact habitats (Radeloff et al. 2010), management of cross-boundary threats including invasive species and fire (EpanchinNiell et al. 2010; Sturtevant et al. 2009), and livable communities where many BLM employees live and benefit from economies tied to place. People in landbased livelihoods are already observing and adapting to climate change-related impacts (Knapp 2011; Knapp et al. 2014; McNeeley and Shulski 2011) and are not only vulnerable to direct climate change impacts, but also indirect impacts of changed decision-making on public lands. Management regimes that are unresponsive to shifts in weather and ecology may have unintentional consequences for the communities that rely on these landscapes.

Our research also shows that agencies with multiple use mandates will likely see synergistic and cumulative reactions and responses to climate change and should be proactive in planning for them. Interviews highlighted that these interactions are already occurring. Three examples include 1) changes in disturbance regimes (fire; bark beetle) are interacting with endangered species to create contexts in which management decisions might change related to land-based livelihoods; 2) earlier or more intense snowstorms may push game on to private land, both increasing competition for forage resources as well as decreasing hunter success; and 3) early melt-off and low river flows may also increase conflict between ranchers and water-based recreation, as ranchers, who often have senior water rights, pull more water for irrigation, thus lowering river flows. Managing for resilience on federal lands is challenging (Benson and Garmestani 2011), but it is critical that managers continue to consider how both policy and local responsiveness can facilitate resilience.

These findings show that public land managers have ability to encourage or dissuade long-term adaptation to climate change given the vast landscapes that are under their control. If managers fail to be responsive to changes in surface water (slow permitting process for new water developments), then ranchers with federal land permits will be unable to distribute livestock in a sustainable manner, potentially leading to over grazing in specific areas. If recreation permits (location, timing, and duration of use) are static, businesses may find that they are unable to utilize them. When and how land managers respond will have a large impact on both the health of land and resources, as well as local economies.

Although local resource users are taking many actions to respond to changes, there are constraints that limit response, due to both individual factors (e.g., costs of leasing additional land), agency-specific factors that increase sensitivity (e.g., temporal mismatches in timing of use in permits and ecological conditions on the ground), and broader regional-international factors (e.g., peak visitation times do not coincide with peak periods for recreational activities). The more managers understand and consider these factors in decision-making, the more likely it will be that land-based livelihoods will weather the changes that they are currently facing.

This approach to understanding vulnerability is important for supporting local efforts at adaptation. Qualitative interviews can help to illustrate patterns of vulnerability as well as local and sector-specific nuances that inform how adaptation should occur. By engaging the perceptions of both BLM staff and permittees, we were able to develop shared understandings, identify barriers to adaptation, and work toward adaptation strategies that are locally appropriate, desirable, and practical.

\section{Conclusions}

Residents of rural, western communities with landbased livelihoods are often dependent on public land and the ecosystem services they provide. Governance of these lands can decrease permittee adaptive capacity through policies and internal planning documents that restrict prompt adaptation, as well as limitations on agency personnel to manage for adaptation. Long-term planning documents that guide management, overworked federal employees with a backlog of projects, little top-down guidance, and limited resources for monitoring conspire for a situation in which responsivity is limited. This suite of challenges has made 
responses heterogeneous across landscapes, based on local agency leadership and willingness to consider and address the issue. For rural economies across the western United States, this could have large repercussions as response to climate change may be spotty or nonexistent. Given the dependence of rural communities in the western United States on public lands, this could have significant impacts across the western United States.

Our findings provided examples of how managers could think proactively about planning for multiple use by developing trust with permittees, integrating flexibility into RMPs, and facilitating new skill development in managers. In both FOs, there were examples of how trust led to local-level flexibility within the bounds of the RMP. Participants described how RMPs could include if-then statements and/or thresholds of concern, which could build flexibility into plans. Finally, managers need new skills including understanding complex trade-offs, building relationships of trust with permittees, and thinking proactively about both funding of monitoring as well as rangeland improvements. We hope that this project will help the BLM in considering how to be a better neighbor to land-based livelihoods that depend on public lands.

Acknowledgments. This project was funded by the Bureau of Land Management (Assistance Agreement L15AC00072).

\section{APPENDIX A}

\section{BLM Interview Questions}

This appendix documents the actual wording of the BLM interview questions. The associated concepts from the analytical framework are in parentheses.

- What is your position here and how long have you been in it?

- What have you observed in terms of impacts of climate variability or change on the BLM lands or resources you manage? (exposure)

- What management decisions do you have to make that are affected by seasonality changes? And by weather or climate extremes? (sensitivity; adaptive capacity)

- How are the users of BLM lands you manage impacted by those climate changes or extremes? (exposure; sensitivity)

- What are the related management decisions you have to make? (sensitivity; adaptive capacity)

- What kind of flexibility do you have in making those decisions? (adaptive capacity
- Are there barriers to your management flexibility? If so, what are they? (adaptive capacity)

- What information would be helpful to you in terms of understanding BLM land users related to their risks or vulnerabilities to climate variability and change?

- Who do you think is important to interview for this research?

- Anything else we haven't discussed you feel is important for this research?

\section{APPENDIX B}

\section{BLM Permittee Interview Questions}

This appendix documents the actual wording of the BLM permittee interview questions. The associated concepts from the analytical framework are in parentheses.

- Could you start by describing your history in this area? How long have you been involved with (ranching/outfitting/recreation) and in what capacity?

- Could you please describe your operation, how long you have been associated with it, and the goods and/or services you produce?

- Could you talk about the seasonality of your operation? (exposure)

- What activities do you undertake and when do they occur?

- What role do the public lands you use play in your overall operation? (sensitivity)

- Does that role change throughout the year?

- (If permits are not specifically mentioned or described): Could you describe the permit that allows you to access and use BLM-managed lands?

- Have you observed any changes to these lands or resources as a result of changes in climate or weather? (exposure)

- What risks do these changes pose to your operations and how have you managed or planned for them? (sensitivity; adaptive capacity)

- How does BLM management affect your ability to adapt to weather and climate related risks? (sensitivity; adaptive capacity)

- Are there any other related barriers or constraints that exist for your management?

- Has your permit ever changed to adapt to weather or climate related risks? If so under what conditions? (adaptive capacity)

- What options do you have to adapt to a situation in which your permit has been restricted/reduced/or changed in some other way? (sensitivity; adaptive capacity) 
- What types of changes in BLM management would you like to see in order to better respond to climate and weather related risks? (adaptive capacity)

- If flexibility is mentioned: Could you provide some concrete examples of what this flexibility might look like?

- Is there anything else we haven't discussed that you feel is important for this research?

\section{REFERENCES}

Adger, W. N., 2006: Vulnerability. Global Environ. Change, 16, 268-281, https://doi.org/10.1016/j.gloenvcha.2006.02.006.

Agrawal, A., and N. Perrin, 2008: Climate adaptation, local institutions, and rural livelihoods. International Forestry Resources and Institutions Program Working Paper W08I-6, 17 pp., http://www.umich.edu/ ifri/Publications/W08I6\% 20 Arun $\% 20$ Agrawal $\% 20$ and $\% 20$ Nicolas $\% 20$ Perrin.pdf.

Archie, K. M., L. Dilling, J. B. Milford, and F. C. Pampel, 2012: Climate change and western public lands: A survey of U.S. federal land managers on the status of adaptation efforts. Ecol. Soc., 17, art20, https://doi.org/10.5751/ES-05187-170420.

,,--- , and — 2014: Unpacking the information barrier': Comparing perspectives on information as a barrier to climate change adaptation in the interior mountain West. J. Environ. Manage., 133, 397-410, https://doi.org/10.1016/ j.jenvman.2013.12.015.

Babcock, S., and K. Kachur, 2014: 2014 Colorado Statewide Comprehensive Outdoor Recreation Plan. Colorado Parks \& Wildlife, $187 \mathrm{pp}$.

Benson, M. H., and A. S. Garmestani, 2011: Can we manage for resilience? The integration of resilience thinking into natural resource management in the United States. Environ. Manage., 48, 392-399, https://doi.org/10.1007/s00267-011-9693-5.

Bierbaum, R., and Coauthors, 2013: A comprehensive review of climate adaptation in the United States: More than before, but less than needed. Mitigation Adapt. Strategies Global Change, 18, 361-406, https://doi.org/10.1007/s11027-012-9423-1.

Blades, J. J., P. Z. Klos, K. B. Kemp, T. E. Hall, J. E. Force, P. Morgan, and W. T. Tinkham, 2016: Forest managers' response to climate change science: Evaluating the constructs of boundary objects and organizations. For. Ecol. Manage., 360, 376-387, https://doi.org/10.1016/j.foreco.2015.07.020.

BLM, 2016: Bureau of Land Management (BLM) final planning rule. Part II, Federal Register, Vol. 81, No. 238, 89580-89671, https:// www.govinfo.gov/content/pkg/FR-2016-12-12/pdf/2016-28724.pdf.

Briske, D. D., L. A. Joyce, H. W. Polley, J. R. Brown, K. Wolter, J. A. Morgan, B. A. McCarl, and D. W. Bailey, 2015: Climatechange adaptation on rangelands: Linking regional exposure with diverse adaptive capacity. Front. Ecol. Environ., 13, 249256, https://doi.org/10.1890/140266.

Bryant, A., and K. Charmaz, Eds., 210: The SAGE Handbook of Grounded Theory. SAGE, $656 \mathrm{pp}$.

Bryman, A., 2016: Social Research Methods. 5th ed. Oxford University Press, 824 pp.

Charnley, S., H. Gosnell, K. L. Wendel, M. M. Rowland, and M. J. Wisdom, 2018: Cattle grazing and fish recovery on US federal lands: Can social-ecological systems science help? Front. Ecol. Environ., 16, S11-S22, https://doi.org/10.1002/fee.1751.

Colorado Parks \& Wildlife, 2019: Ranching for wildlife. Accessed 19 July 2019, https://cpw.state.co.us/rfw.
Creswell, J. W., 2014: Research Design: Qualitative, Quantitative, and Mixed Methods Approaches. SAGE, $305 \mathrm{pp}$.

Ellenwood, M. S., L. Dilling, and J. B. Milford, 2012: Managing United States public lands in response to climate change: A view from the ground up. Environ. Manage., 49, 954-967, https://doi.org/10.1007/s00267-012-9829-2.

Epanchin-Niell, R. S., M. B. Hufford, C. E. Aslan, J. P. Sexton, J. D. Port, and T. M. Waring, 2010: Controlling invasive species in complex social landscapes. Front. Ecol. Environ., 8, 210-216, https://doi.org/10.1890/090029.

Ford, J. D., and B. Smit, 2004: A framework for assessing the vulnerability of communities in the Canadian Arctic to risks associated with climate change. Arctic, 57, 389-400.

Glaser, B. G., and Strauss, A. L., 1967: The Discovery of Grounded Theory: Strategies for Qualitative Research. Aldine, $271 \mathrm{pp}$.

Gonzalez, P., and Coauthors, 2018: Southwest. Impacts, Risks, and Adaptation in the United States: Fourth National Climate Assessment, Vol. II, D. R. Reidmiller et al., Eds., U.S. Global Change Research Program, 1101-1184.

Gordon, E., D. Ojima, A. Childress, T. Jedd, R. Kleian, J. Lukas, and R. McKeown, 2014: Colorado Climate Change Vulnerability Study. University of Colorado Boulder and Colorado State University Energy Office Rep., 175 pp., https://studylib.net/doc/ 18803633/colorado-climate-change-vulnerability-study.

Hamilton, J. M., D. J. Maddison, and R. S. J. Tol, 2005: Climate change and international tourism: A simulation study. Global Environ. Change, 15, 253-266, https://doi.org/10.1016/ j.gloenvcha.2004.12.009.

Hand, M. S., and M. Lawson, 2018: Effects of climate change on recreation in the Northern Rockies. Advances in Global Change Research, J. E. Halofsky and D. L. Peterson, Eds., Vol. 63, Climate Change and Rocky Mountain Ecosystems, Springer International Publishing, 169-188.

Hingham, C. M., and J. Hall, 2005: Tourism, Recreation and Climate Change. Channel View Publications, 336 pp.

IPCC, 2013: Climate Change 2013: The Physical Science Basis. Cambridge University Press, 1535 pp., https://doi.org/10.1017/ CBO9781107415324.

Joyce, L. A., D. D. Briske, J. R. Brown, H. W. Polley, B. A. McCarl, and D. W. Bailey, 2013: Climate change and North American rangelands: Assessment of mitigation and adaptation strategies. Rangel. Ecol. Manage., 66, 512-528, https://doi.org/ 10.2111/REM D-12-00142.1.

Kemp, K. B., J. J. Blades, P. Z. Klos, T. E. Hall, J. E. Force, P. Morgan, and W. T. Tinkham, 2015: Managing for climate change on federal lands of the western United States: Perceived usefulness of climate science, effectiveness of adaptation strategies, and barriers to implementation. Ecol. Soc., 20, art17, https://doi.org/10.5751/ES-07522-200217.

Knapp, C. N., 2011: Connected to the land: Social resilience and vulnerability assessment of land-based livelihoods in the Gunnison Basin, Colorado. Nature Conservancy and Gunnison Climate Working Group Doc., 34 pp., https://www.fs.usda.gov/rmrs/ documents-and-media/connected-land-social-resilience-andvulnerability-assessment-land-based.

- F. S. Chapin III, G. P. Kofinas, N. Fresco, C. Carothers, and A. Craver, 2014: Parks, people, and change: The importance of multistakeholder engagement in adaptation planning for conserved areas. Ecol. Soc., 19, art16, https://doi.org/10.5751/ ES-06906-190416.

Laatsch, J., and Z. Ma, 2016: Climate-change communication within public natural resource agencies: Lessons learned from 
the U.S. Forest Service. Soc. Nat. Resour., 29, 1169-1185, https:// doi.org/10.1080/08941920.2015.1107790.

Liu, Z., W. J. Smith, and A. S. Safi, 2014: Rancher and farmer perceptions of climate change in Nevada, USA. Climatic Change, 122, 313-327, https://doi.org/10.1007/s10584-013-0979-x.

McNeeley, S. M., 2012: Examining barriers and opportunities for sustainable adaptation to climate change in Interior Alaska. Climatic Change, 111, 835-857, https://doi.org/10.1007/s10584011-0158-x.

, and M. D. Shulski, 2011: Anatomy of a closing window: Vulnerability to changing seasonality in Interior Alaska. Global Environ. Change, 21, 464-473, https://doi.org/10.1016/ j.gloenvcha.2011.02.003.

, C. N. Knapp, T. L. Even, J. Gioia, and J. Nave, 2017a: Colorado Bureau of Land Management: Social vulnerability assessment. Colorado State University Natural Resource Ecology Laboratory Rep., 209 pp., https://cnhp.colostate.edu/ wp-content/uploads/download/documents/misc/COBLM_SocialVulnerability-Assessment_Final-Report_7-26-19.pdf.

_- T. L. Even, J. B. M. Gioia, C. N. Knapp, and T. A. Beeton, 2017b: Expanding vulnerability assessment for public lands: The social complement to ecological approaches. Climate Risk Manage., 16, 106-119, https://doi.org/10.1016/ j.crm.2017.01.005.

Millennium Ecosystem Assessment Program, Ed., 2005: Ecosystems and Human Well-Being: Synthesis. Island Press, 137 pp.

Morton, J. F., 2007: The impact of climate change on smallholder and subsistence agriculture. Proc. Natl. Acad. Sci. USA, 104, 19680-19 685, https://doi.org/10.1073/pnas.0701855104.

Moser, S. C., and J. A. Ekstrom, 2010: A framework to diagnose barriers to climate change adaptation. Proc. Natl. Acad. Sci. USA, 107, 22 026-22 031, https://doi.org/10.1073/pnas.1007887107.

National Park Service, 2010: National Park Service climate change response strategy. NPS, https://www.adaptationclearinghouse.org/ resources/national-park-service-climate-change-responsestrategy.html.

__ 2012: National Park Service climate change action plan 2012-2014. NPS, https://www.adaptationclearinghouse.org/ resources/national-park-service-climate-change-action-plan2012-2014.html.

Nave, J., C. N. Knapp, and S. McNeeley, 2020: Planning for change? Assessing the integration of climate change and landbased livelihoods in Colorado BLM planning documents. Reg. Environ. Change, 20, 29, https://doi.org/10.1007/s10113-02001590-0.

Neely, B., and Coauthors, 2011: Gunnison Basin: Vulnerability assessment. Gunnison Climate Working Group Rep., 262 pp., http://www.cnhp.colostate.edu/download/documents/ 2011/Gunnison-CC-Vulnerability-Assessment_and_AppendicesFULL_REPORT-Jan_9_2012.pdf.

Obama, B., 2009: Federal leadership in environmental, energy, and economic performance. Executive Order 13514, Part VII, Federal Register, Vol. 74, No. 194, 52117-52127, https:// www.federalregister.gov/documents/2009/10/08/E9-24518/ federal-leadership-in-environmental-energy-and-economicperformance.

_- 2013: Preparing the United States for the impacts of climate change. Office of the Press Secretary, https:// obamawhitehouse.archives.gov/the-press-office/2013/11/01/ executive-order-prEPAring-united-states-impacts-climatechange.

_ 2015: Planning for federal sustainability in the next decade. Office of the Press Secretary, https://obamawhitehouse.archives.gov/ the-press-office/2015/03/19/executive-order-planning-federalsustainability-next-decade.

Radeloff, V. C., S. I. Stewart, T. J. Hawbaker, U. Gimmi, A. M. Pidgeon, C. H. Flather, R. B. Hammer, and D. P. Helmers, 2010: Housing growth in and near United States protected areas limits their conservation value. Proc. Natl. Acad. Sci. USA, 107, 940-945, https://doi.org/10.1073/pnas.0911131107.

Rasker, R., P. H. Gude, and M. Delorey, 2013: The effect of protected federal lands on economic prosperity in the non-metropolitan west. J. Reg. Anal. Policy, 43, 110-122, http://www.jrap-journal.org/ pastvolumes/2010/v43/v43_n2_a2_rasker_etal.pdf.

Reeves, M. C., and K. E. Bagne, 2016: Vulnerability of cattle production to climate change on U.S. rangelands. USDA General Tech. Rep. RMRS-GTR-343, 39 pp., https:// www.fs.fed.us/rm/pubs/rmrs_gtr343.pdf.

Reidmiller, D. R., C. W. Avery, D. R. Easterling, K. E. Kunkel, K. L. M. Lewis, T. K. Maycock, and B. C. Stewart, Eds., 2018: Impacts, Risks, and Adaptation in the United States: Fourth National Climate Assessment. U.S. Global Change Research Program, 1515 pp., https://doi.org/10.7930/NCA4.2018.

Richardson, R. B., and J. B. Loomis, 2004: Adaptive recreation planning and climate change: A contingent visitation approach. Ecol. Econ., 50, 83-99, https://doi.org/10.1016/ j.ecolecon.2004.02.010.

Rimbey, N. R., J. A. Tanaka, and L. A. Torell, 2015: Economic considerations of livestock grazing on public lands in the United States of America. Animal Front., 5, 32-35, https:// doi.org/10.2527/AF.2015-0044

Ritchie, J., 2013: Qualitative Research Practice: A Guide for Social Science Students and Researchers. 2nd ed. SAGE Publications Ltd, $456 \mathrm{pp}$.

Scott, D., J. Dawson, and B. Jones, 2008: Climate change vulnerability of the US Northeast winter recreation-Tourism sector. Mitigation Adapt. Strategies Global Change, 13, 577-596, https://doi.org/10.1007/s11027-007-9136-z.

Stowell, C., 2016: Federal lands in the west: A few facts and figures. Accessed 19 June 2019, https://www.westernplanner.org/ 201604issue/2017/8/9/federal-lands-in-the-west-a-few-facts-andfigures.

Sturtevant, B. R., B. R. Miranda, J. Yang, H. S. He, E. J. Gustafson, and R. M. Scheller, 2009: Studying fire mitigation strategies in multi-ownership landscapes: Balancing the management of fire-dependent ecosystems and fire risk. Ecosystems, 12, 445461, https://doi.org/10.1007/s10021-009-9234-8.

Timberlake, T. J., and C. A. Schultz, 2017: Policy, practice, and partnerships for climate change adaptation on US national forests. Climatic Change, 144, 257-269, https://doi.org/10.1007/ s10584-017-2031-z.

Trump, D. J., 2017: Presidential executive order on promoting energy independence and economic growth. https://www.whitehouse.gov/ presidential-actions/presidential-executive-order-promotingenergy-independence-economic-growth/.

Turner, B. L., and Coauthors, 2003: A framework for vulnerability analysis in sustainability science. Proc. Natl. Acad. Sci., 100, 8074-8079, http:/www.pnas.org/lookup/doi/10.1073/ pnas. 1231335100 .

USDA, 2012: County level data. Census of Agriculture for Colorado, Vol. 1, https://www.nass.usda.gov/Publications/ AgCensus/2012/Full_Report/Volume_1,_Chapter_2_County_Level/ Colorado/.

U.S. Department of the Interior, 2014: Climate change adaptation plan. Office of Policy Analysis \& Climate Change Working Group Doc., 47 pp., https://www.doi.gov/sites/doi.gov/files/ 
migrated/greening/sustainability_plan/upload/2014_DOI_Climate_ Change_Adaptation_Plan.pdf.

2017a: American energy independence. Secretary of the Interior Order 3349, 5 pp., https://www.doi.gov/sites/doi.gov/ files/elips/documents/3349\%20\%20-American \%20Energy \% 20Independence.pdf.

— 2017b: Rescinding authorities inconsistent with Secretary's Order 3349, “American Energy Independence.” Deputy Secretary of the Interior Order 3360, 3 pp., https://www.eenews.net/assets/2018/01/ 05/document_gw_04.pdf.

_ 2019: Our priorities. U.S. Department of the Interior, https:// www.doi.gov/ourpriorities.

USFS, 2009: Cover letter: Considering climate change in land management and project planning. U.S. Forest Service Doc., 2 pp., https://www.fs.fed.us/emc/nepa/climate_change/ includes/cc_cover_letter.pdf.

Veblen, K. E., D. A. Pyke, C. L. Aldridge, M. L. Casazza, T. J. Assal, and M. A. Farinha, 2014: Monitoring of livestock grazing effects on Bureau of land management land. Rangeland Ecol. Manage., 67, 68-77, https://doi.org/10.2111/REM-D-12-00178.1.
Verbos, R. I., B. Altschuler, and M. T. J. Brownlee, 2018: Weather studies in outdoor recreation and nature-based tourism: A research synthesis and gap analysis. Leisure Sci., 40, 533-556, https://doi.org/10.1080/01490400.2017.1325794.

Warziniack, T. W., and Coauthors, 2018: Effects of climate change on ecosystem services. USDA Forest Service Tech. Rep. RMRSGTR-375, 376-403, https://www.fs.fed.us/rm/pubs_series/rmrs/gtr/ rmrs_gtr375/rmrs_gtr375_376_403.pdf.

White, E. M., and D. J. Stynes, 2008: National forest visitor spending averages and the influence of trip-type and recreation activity. J. For., 17-24.

Wyborn, C., L. Yung, D. Murphy, and D. R. Williams, 2015: Situating adaptation: How governance challenges and perceptions of uncertainty influence adaptation in the Rocky Mountains. Reg. Environ. Change, 15, 669-682, https://doi.org/ 10.1007/s10113-014-0663-3.

Yung, L., N. Phear, A. DuPont, J. Montag, and D. Murphy, 2015: Drought adaptation and climate change beliefs among working ranchers in Montana. Wea. Climate Soc., 7, 281-293, https://doi.org/10.1175/WCAS-D-14-00039.1. 